\title{
FIRST REPORT ON THE LONG-TERM PRESENCE OF COMMON BOTTLENOSE DOLPHINS (Tursiops truncatus) OFF Central ChILE
}

\author{
Fernando Díaz-Aguirre2, , Sergio Navarrete 2 , Carla Salinas ${ }^{2}$, Luciano Hiriart ${ }^{2}$, \\ Víctor Castillo², Attia Zerega², Richard Ritter ${ }^{3}$ and Consuelo Castilla ${ }^{2}$
}

The common bottlenose dolphin (Tursiops truncatus) is distributed in tropical and temperate oceans worldwide. In Chile its presence has been reported from Arica $\left(18^{\circ} 29^{\prime} S\right.$ ) to Cape Skyring (4549'S) (Aguayo-Lobo et al., 1998; Aguayo et al., 2003) including San Félix and San Ambrosio Islands, Juan Fernández Archipelago (Gilmore, 1971; Aguayo, 1975), and Sala y Gómez and Pascua (Easter) Islands (Cardenas et al., 1986). Despite this wide range of continuous distribution, long-term reports on the presence of this species are restricted to the Reserva Nacional Pinguino de Humboldt $\left(29^{\circ} 02^{\prime} S\right)$ in the north coast of Chile, where a resident population has been documented (Gonzalez et al., 1989; Gibbons, 1992; Perez et al., 20044; Thomas, 2005). In this note, we make the first report on the long-term presence of common bottlenose dolphins off central Chile.

The study area comprised the waters around Punta Curaumilla, V Region, Chile, and extends from Punta

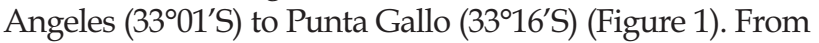

November 2004 to September 2006, December 2006 to March 2007 and August 2007 we conducted 51 days of landbased observations and 14 boat-based surveys within the study area. Observations lasted on average 4.86h $(\mathrm{SD}=3.1)$ and were carried out during daylight hours of 07:00 - 20:00 depending on season, visibility and light conditions. Landbased observations were conducted from cliffs located on different vantage points using $16 \times 50$ and $7 \times 50$ binoculars. Boat-based surveys were conducted parallel to the coastline at a distance from 1 to $8 \mathrm{~km}$ offshore. Position was recorded using a portable GPS at 10 minute intervals.

When a common bottlenose dolphin group was sighted it was followed until it was lost (group follow protocol) (Mann, 1999). A group of dolphins was defined as any aggregation of one or more animals observed in association, moving in the same direction and usually engaging in the same behavior (Shane, 1990). All the observations were conducted at sea Beaufort state $<3$.

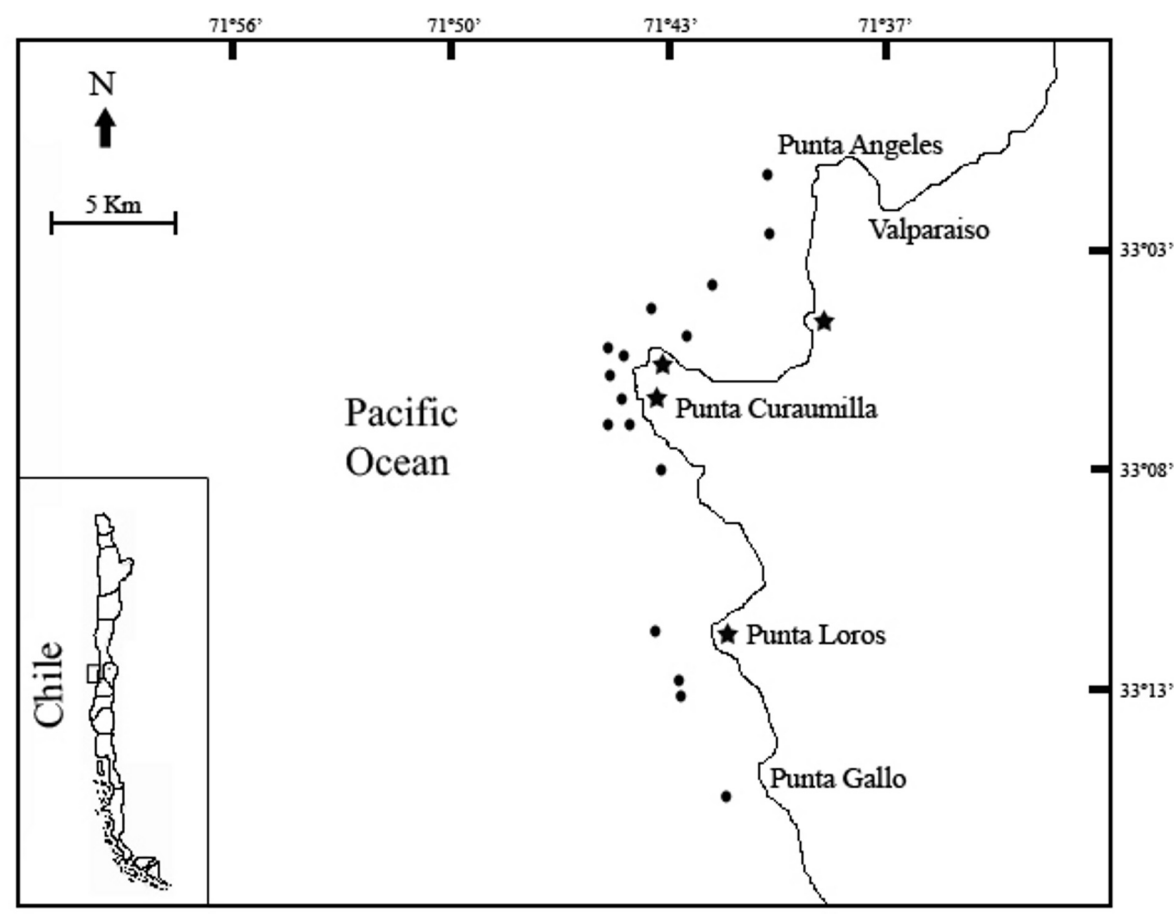

Figure 1. Study area; $(\bullet)$ initial GPS coordinates of 16 common bottlenose dolphin groups observed during boat-based surveys; (*) location of land-based observations points.

\footnotetext{
${ }^{1}$ Received on 11 August 2008. Accepted on 4 September 2009. Managed by Nélio Barros / Daniel Palacios.

${ }^{2}$ Facultad de Ecología y Recursos Naturales, Escuela de Ciencias del Mar, Universidad Andrés Bello, Republica 217, Santiago, Chile.

${ }^{3}$ Facultad de Ciencias, Escuela de Biología Marina, Universidad de Magallanes, Bulnes 01855, Punta Arenas, Chile.

* Corresponding author, e-mail: ferna.diaz@uandresbello.edu.

${ }^{4}$ Pérez, M. J., Thomas, F., Oliva, D. and Moraga, R. (2004) Foto-identificación del delfín nariz de botella, Tursiops truncatus, en la Reserva Nacional Pingüino de Humboldt: aplicación y resultados preliminares. Page 179 in Abstracts, XXIV Congreso de Ciencias del Mar, 17-20 May, Coquimbo, Chile.
} 
The survey effort included $315.9 \mathrm{~h}$ spent in the area, of which $68.4 \mathrm{~h}$ were of direct observation on the animals. A total of 2636 dolphins in 102 groups were recorded. Dolphins occurred year-round throughout the study area (Figure 1) and were encountered on $81.5 \%$ of the surveys. Sightings ranged from 5 to 227 minutes with an average of 40.3 minutes $(S D=42.6)$. Groups of dolphins followed during boat surveys occurred regularly within two kilometers from shore $(73 \%$; $n$ recorded positions $=70$ ) and showed movements parallel to the coastline during all observations.

This study represents the first long-term documentation of this species in the nearshore waters of the $\mathrm{V}$ Region of Chile and provides evidence of a previously undocumented population of common bottlenose dolphins inhabiting central Chile. Preliminary information on photo-identification (Díaz-Aguirre et al., $2007^{5}$ ) suggests that some individuals are present yearround, indicating some degree of fidelity to the study area. Although we have not confirmed using genetic techniques, the distribution and movement pattern of dolphins within the study area suggest that this population probably pertains to the coastal ecotype. However when comparing with other coastal populations (e.g., Wursig and Wursig, 1979; Shane, 1990; Hanson and Defran, 1993; Morteo et al., 2004; Bearzi, 2005), this dolphins apparently use a wide stretch of coastline which could be related with the distribution of their prey and the open characteristics of the environment. Indeed, most of the foraging and feeding behaviors observed during the study period were associated with flocks of Pelicans (Pelecanus thagus) and Peruvian Boobies (Sula variegata) suggesting that they were feeding on neritic fishes near the surface contrary to what its reported for other coastal populations where dolphins prefers to feed on bottom prey (Scott and Chivers, 1990; Hanson and Defran, 1993; Rossbach and Herzing, 1997; Bearzi, 2005). The long-term presence of this population could be related to the high levels of productivity in the area due to upwelling events off Punta Curaumilla (Johnson et al., 1980; Fonseca and Farias, 1987; Avaria et al., 1989; Silva and Valdenegro, 2003).

Current anthropogenic threats to dolphins inhabiting this region include entanglement in fishing gear, environmental contaminants, and disturbance and collisions with boats. These threats are particularly relevant north of Valparaiso harbor where human population size, coastal development and boat traffic could be of concern. In Chile, the common bottlenose dolphin has been classified as data deficient (AguayoLobo et al., 1998). Therefore, long-term research on this and other populations are of special importance for the conservation of the species, as well as monitoring the health of their habitat and the ecosystem over long periods of time.

\section{Acknowledgements}

We wish to thank Paula Plaza, Andrea Cabrera, Pilar Molina, Felipe Soto, Felipe Thomas and all the volunteers who helped during data collection in the field. Two anonymous referees made helpful comments on the manuscript. This research was partially funded by Dirección de Asuntos Estudiantiles (DAE) and Escuela de Ciencias del Mar, Universidad Andrés Bello. We also thank Gaston Aguirre for providing complementary funding. Special thanks to the local fishermen community at Quintay, especially to our boat captains Johnny and Tablon for their great support during long hours at sea. Finally we acknowledge the unconditional support of our families during the development of this project.

\section{References}

Aguayo, A.L. (1975) Progress report on small cetacean research in Chile. Journal of the Fisheries Research Board of Canada 32: 1123-1143.

Aguayo-Lobo, A., Torres, D.N. And Acevedo, J.R. (1998) Los mamíferos marinos de Chile: I. Cetácea. Serie Científica Instituto Nacional Antartico Chileno 48: 19-159.

Aguayo, A.L., Acevedo, J.R. And Vallejos, V.M. (2003) Distribución, biodiversidad de mamíferos marinos y estructura génica de cetáceos en las aguas marinas de la XI región de Chile. Libro de resúmenes, taller sobre los resultados del Crucero CIMAR VIII fiordos. Valparaíso: 81-87.

Avaria, S., Palma, S., Sievers, H. and Silva, N. (1989) Revisión sobre aspectos oceanográficos físicos, químicos y planctologicos de la bahía de Valparaíso y áreas adyacentes. Biología Pesquera 18: 67-96.

BEARZI, M. (2005) Aspects of the ecology and behavior of bottlenose dolphins (Tursiops truncatus) in Santa Monica Bay, California. Journal of Cetacean Research and Management 7(1): 75-83.

Cardenas, J.C., Stutzin, M.E., Oporto, J.E., Cabello, C. and Torres, D. (1986) Manual de identificación de los cetáceos chilenos. Proyectos WH-445 Cetáceos Chile WWF-US/CODEFF-CHILE. 102 pp.

Fonseca, T.R. And Farias, M. (1987) Estudio del proceso de surgencia en la costa chilena utilizando percepción remota. Investigación Pesquera (Chile) 34: 33-46.

GibBons, J.E. (1992) Estudio sobre conducta y dinámica grupal del tursión, Tursiops truncatus, en Isla Chañaral, III Región, Chile. Master Thesis, Facultad de Ciencias, Universidad de Chile, Santiago. 74 pp.

GILMORE, R.M. (1971) Observations on marine mammals and birds off the coast of southern and central Chile, early winter 1970. Antartic Journal of the United States 6(2): 10-11.

\footnotetext{
${ }^{5}$ Díaz-Aguirre, F., Navarrete, S., Castillo, V., Salinas, C. and Castilla, C. (2007) Preliminary observations on the behavioral ecology of the bottlenose dolphin (Tursiops sp.) in the open nearshore waters off central Chile. Page 95 in Abstracts, XVII Biennial Conference on the Biology of Marine Mammals, 29 November - 3 December, Cape Town, South Africa.
} 
Gonzalez, J.V., Capella, J.A. And Gibbons, J.E. (1989) Delfines nariz de botella Tursiops truncatus (Montagu, 1821) habitando frente a Isla Chañaral, Provincia de Huasco, Chile. Estudios Oceanológicos 8: 67-71

Hanson, M.T. And Defran, R.H. (1993) The behavior and feeding ecology of the Pacific coast bottlenose dolphin (Tursiops truncatus). Aquatic Mammals 19(3): 127-142.

Johnson, D.T., FonsecA, I.H. And Sievers, H. (1980) Upwelling in the Humboldt coastal current near Valparaíso, Chile. Journal of Marine Research 38(1): 1-16.

MAnN, J. (1999) Behavioral sampling methods for cetaceans: A review and critique. Marine Mammal Science 15: 102-122.

Morteo, E., Heckel, G., Defran, R.H. and Shramm, Y. (2004) Distribución, movimientos y tamaño de grupo del tursión (Tursiops truncatus) al sur de Bahia San Quintín, Baja California, México. Ciencias Marinas 30(1a): 35-46.

Rossbach, K.A. AND Herzing, D.L. (1997) Underwater observation of benthic feeding bottlenose dolphins (Tursiops truncatus) near Grand Bahamas Island, Bahamas. Marine Mammal Science 13(3): 498-503.
Scott, M.D. And ChIvers, S.J. (1990) Distribution and herd structure of bottlenose dolphins in the Eastern Tropical Pacific Ocean. Pages 387-402 in Leatherwood, S. and Reeves, R. R. (Eds) The Bottlenose Dolphin. Academic Press, San Diego, CA, USA.

SHANE, S.H. (1990) Behavior and ecology of the bottlenose dolphin at Sanibel Island, Florida. Pages 245-265 in Leatherwood, S. and Reeves, R. R. (Eds) The Bottlenose Dolphin. Academic Press, San Diego, CA, USA.

Silva, N. And Valdenegro, A. (2003) Evolución de un evento de surgencia frente a Punta Curaumilla, Valparaíso. Investigaciones Marinas 31(2): 73-89.

Thomas, F.A. (2005) Residencia del delfín nariz de botella Tursiops truncatus (Montagu, 1821) en la Reserva Nacional Pingüino de Humboldt, Chile. BSc Thesis, Universidad de Valparaíso, Chile. 38 pp.

WÜRSIG, B.AND WÜRsIG, M. (1979) Behavior and ecology of the bottlenose dolphin, Tursiops truncatus, in the south Atlantic. Fishery Bulletin 77(2): 399- 412. 